\title{
РАЗРАБОТКА ФОТОСЕНСИБИЛИЗАТОРОВ НА ОСНОВЕ КАТИОННЫХ ПОРФИРИНОВ ДЛЯ АНТИМИКРОБНОЙ ФОТОДИНАМИЧЕСКОЙ ТЕРАПИИ
}

\author{
И.О.Савельева, А.Ю. Усанёв, К.С. Завельская, К.А. Жданова, Н.А. Брагина \\ МИРЭА-Российский технологический университет, \\ 119571, РФ, Москва, пр-т Вернадского, 86.
}

DOI: 10.19163/MedChemRussia2021-2021-380

E-mail: inga.saveleva.96@mail.ru

Как альтернативный подход к лечению инфекционных заболеваний развивается метод антимикробной фотодинамической терапии (АФДТ), в основе которого лежит процесс инактивации микроорганизмов с помощью активных форм кислорода, вырабатываемых при облучении светом фоточувствительного агента - фотосенсибилизатора. Широко используемыми соединениями в данной области являются производные порфиринов из-за их высоких коэффициентов молярной экстинкции, простоты синтеза и стабильности макроцикла для проведения дальнейших химических модификаций [1].

В качестве потенциальных фотосенсибилизаторов для АФДТ был синтезирован ряд катионных производных порфиринов в виде свободных оснований и комплексов с Zn(II) с различным числом зарядов на периферии макроцикла. Целевые вещества были получены монопиррольной конденсацией по методу Линдсея с последующим введением терминальных азотсодержащих гетероциклических групп. Катионные производные порфиринов были охарактеризованы данными мультиядерной ЯМР-и УФ-спектроскопии, хроматомасс-спектрометрии. В настоящее время проводятся исследования фотофизических, фотохимических и антимикробных свойств целевых соединений.

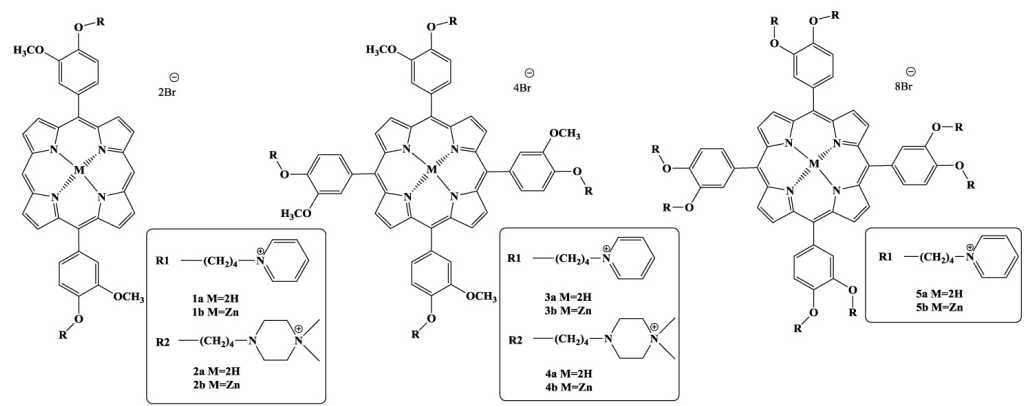

Работа выполнена при поддержке Российского Научного Фонда (проект №20-73-00286).

\section{Литература}

[1] K.A. Zhdanova, I.O. Savelyeva, A.A. Ignatova, M.A. Gradova, O.V. Gradov, A.V. Lobanov, A.V. Feofanov, A.F. Mironov, N.A. Bragina, Dyes and Pigments. 2020,181, 108561.

$$
-380-
$$

